\title{
Population dynamics of Cockroaches (Pterygota: Blattodea) identified from hospitals of Quetta, Balochistan
}

\author{
Saira Gul ${ }^{1}$, Asmatullah Kakar ${ }^{2 *}$, Kamran Taj $^{3}$, Farhat Abbas ${ }^{3}$, Nosheen \\ Rafique $^{4}$ and Sehar Gul ${ }^{5}$ \\ 1. Islamia Girls Degree College, Quetta-87300-Pakistan \\ 2. Department of Zoology, University of Balochistan, Quetta-87300-Pakistan \\ 3. Center of Advanced Study in Vaccinology and Biotechnology (CASVAB), University of Balochistan, Quetta- \\ 87300-Pakistan \\ 4. Department of Zoology, SBK Women University, Quetta-87300-Pakistan \\ 5. Department of Micro-Biology, University of Balochistan, Quetta-87300-Pakistan \\ *Corresponding author's email: asmardanzai@yahoo.com \\ Citation \\ Saira Gul, Asmatullah Kakar, Kamran Taj, Farhat Abbas, Nosheen Rafique and Sehar Gul. Population dynamics of \\ Cockroaches (Pterygota: Blattodea) identified from hospitals of Quetta, Balochistan. Pure and Applied Biology. Vol. \\ 6, Issue 4, pp1477-1486. http://dx.doi.org/10.19045/bspab.2017.600159
}

\begin{tabular}{llll}
\hline \hline Received: 01/10/2017 & Revised: 28/11/2017 & Accepted: 29/11/2017 & Online First: 03/12/2017 \\
\hline \hline
\end{tabular}

\section{Abstract}

Cockroaches (Blattodea) are of great medical importance and one of the key group of insect pests in municipal environments. The aim of present study was to recognize the major cockroach species in hospital environments in Quetta capital of Balochoistan province, Pakistan. Three main metropolitan city hospitals (Civil hospital, Bolan Medical Complex (BMC) and Benazir hospitals) were inspected to collect the cockroaches using sticky traps, insect collecting net and hand catch method. 360 specimens of cockroaches were collected over a four-months trapping period during 2016 from different units (ward, cafeteria and lawn) of the selected hospitals. They were identified as five species of cockroaches from three families: Blattidae include Periplaneta americana (Linnaeus, 1758), Blatta orientalis L. and Blatta lateralis L. The Blattellidae and Polyphagidae include Blattella germanica L. and Polyphaga aegyptica L. respectively. From the data of this study it is concluded that $P$. americana from Quetta hospitals showed highest frequency (43.3\%). Wards were noted harbored highest population of five cockroach species (55.8\%) compared to cafeteria (30.8\%) and lawns (13. 4\%). Wards of BMC were more populated (20.8\%) than that of Benazir (18.3\%) and civil hospitals (16. 7\%). While cafeteria of civil hospital was more populated (12.5\%) than Benazir hospital (10.8\%) and BMC (7. 5\%). In contrast, lawns showed lesser frequency (5\%), (4. 2\%) and (4. $2 \%)$ respectively compare to other units. Among wards viz Gynae, Medicine, Surgery, Paeds and Cardiac; $P$. americana showed high frequency $(26.6 \%)$ fallowed by $B$. germanica $(15 \%)$ and $B$. orientalis (14.1\%). Gynae wards were noted more populated (24.2\%) than Medicine (14.2\%), Paeds $(9.2 \%)$ and Surgery $(8.0 \%)$. No cockroach species was recorded from the cardiac wards.

Keywords: Diversity; Cockroach species; Measurement; Hospitals; Quetta

\section{Introduction}

Among the entire fauna, insects have the chief diversity and around $80 \%$ of total recognized animals in the world are insects [1]. Cockroaches are of the most common insects with foremost history of life which 
has been existed since Pennsylvanian period [2]. Fossil evidence indicates that cockroaches have been on earth for over 325 million years [3-7].

Cockroaches belong to the order Blattodea (Dictyoptera) include 3500 described species [1]. Thirty cockroach species are known to be associated with human habitats $[8,9]$. Most abundantly occupied species are Periplaneta americana (American cockroach), Blattella germanica (German cockroach) and Blatta orientalis (Oriental cockroach). Cockroaches are domiciliary pests attracted to moisture, heat and dusk, ranged in size from $0.64 \mathrm{~cm}$ to $7.62 \mathrm{~cm} \mathrm{[10].}$ Cockroaches evoke strong responses and there is often psychological distress and social stigma attached to their presence [11]. Cockroaches been found in sensitive locations such as hospitals, nurseries and care homes, and in commercial kitchens where it is highly probable that they are involved in disease transmission [12]. So, an ideal environment, can enable a single pregnant female cockroach to generates high population thus may spread and uphill the infestation,rate. These insects are covered in isolated sites or holes in walls, but become active at night [13].

In hospitals' environment, cockroaches have been found in intensive care units (ICU), sick rooms, operating unit, medication units and kitchens [14]. As the hospital distributes fundamental needs such as nutrition, moisture, temperature and shelter [15], so cockroach get nutrition from vomits, phlegm, sputum, manure, human viscera [16]. These insects are known to be recycling agent for the degradation of an organic matter [17]. Faecal material and skin casts have been shown to play a key role in the development of human allergies and asthma [18]. Female cockroaches produce more allergens Bla g (25,000- 50,000 units of allergens) in their faeces compare to males (2,000-3,000 units) [19]. Cockroaches are also very mobile through sewer pipeline and assembled on debris containers which are most suitable for their breeding. In case of overcrowding they migrate from other warm areas [20].

Cockroaches have three stages of life include egg, nymph and adult with incomplete metamorphosis. Eggs are deposited by female in a leathery protective capsule called "ootheca" which dropped or glued immediately on any substratum [16]. Among other species the German cockroach female carries the egg loaded capsule near to hatching, and each ootheca consist of 30 to 48 eggs, while other having 10 to 28 eggs in capsule [21]. The newly hatched nymphs have no wings and shed their skins several times before becoming adults. German and brown banded cockroaches may have several generations per year, but the outdoor species may require a year to develop from egg to adult [22].

Dimorphism in cockroaches is distinct where male cockroaches are aerial and dynamic; while female are apetrous or having reduced wings. From evolutionary point of view the demands of mate finding is extremely significant in cockroach. Moreover, in sexual dimorphisms some characters are also included like tergal glands in some male species, shape and size of the pronotum [23].

In this study presence of major cockroach species were investigated in Quetta city hospitals. In addition, the nutritional sites associated with breeding spots and food accessibility sources and morphometric status of the insect under study was also conducted. However, a few studies have been performed on identifying cockroaches from houses at Quetta, but there is not available an inclusive study regarding cockroaches of Quetta hospitals. The aim of this study was, therefore, to identify the chief cockroach species in hospital environments. 


\section{Material and methods}

\section{Study area}

The recent study on cockroach diversity conducted in Center of Advanced Study in Vaccinology and Biotechnology (CASVAB), Faculty of Life Sciences, University of Balochistan Quetta.

\section{Sampling sites and Geographical coordinates}

Three sampling locations viz civil hospital (30¹1'38"N, 670'30"E), Bolan Medical Complex (BMC) (30 09' 60.00" N, 66 56' $\left.59.99^{\prime \prime} \mathrm{E}\right)$, and Benazir hospital $\left(30^{\circ} 11^{\prime}\right.$ $\left.60.00^{\prime \prime} \mathrm{N}, 67^{\circ} 00^{\prime} 60.00^{\prime \prime} \mathrm{E}\right)$ were selected for the study. Cockroach species were detected from three study units of the selected hospitals such as wards, cafeteria and lawns from May 2016 to August 2016.

\section{Method of collection}

Specimens of cockroaches were detected by sticky trap, insect collecting net and by hand catching methods with the help of sterilized gloves. Sticky traps were fixed at suitable places during night time in different wards (Gynae, Medicine, Surgery and Paeds) and cafeteria for 24 hours, while from lawns this insect was captured by hand and insect collecting net. The trapped cockroach species were then shifted to plastic containers bearing Chloroform and brought to laboratory for taxonomical identification. Totally the number of cockroaches trapped from each sampling unit was estimated.

\section{Identification}

Cockroaches were identified to species level based on shape, color, size, wing span, antennae, femur, tibial spines and reproductive organs using the keys described by Chew et al. [24]. Male and female specimens were identified on the presences or absences of styli between cerci.

\section{Results and discussion}

From a total of 360 cockroaches detected from the city hospitals, five species of the insect had been identified namely, Periplaneta americana (Linnaeus, 1758),
Blatta orientalis L., Blatta lateralis L., Blattella germanica L. and Polyphaga aegyptiaca. The first three known species were from the family Blattidae, and the remaining two from Blattellidae and Polyphagidae respectively. Overall population frequency of cockroach species was high in wards (55.8\%) compared to cafeteria $(30.8 \%)$ and lawns (13.4\%) of selected hospitals. The American cockroach, $P$. americana was the most abundant comprising $43.3 \%$ of all cockroaches trapped. The other identified species in terms of abundance were the German cockroach, B. germinca $(31.6 \%)$, then Oriental cockroach (B. orientalis) (20.8\%), Turkistan cockroach, B. lateralis (3.3\%) and Egyptian cockroach, P. aegyptiaca $(0.8 \%)$. Masood et al. [25] reported previously American and German cockroach of the family Blattidae, and Taj et al. [26] reported five species from three families (Polyphagidae, Blattidae and Blattellidae) from houses in Quetta showed Periplaneta americana was the most common with abundance $(31 \%)$ followed by Blatta orientalis (26\%), Blattella germanica (22\%), Blatta lateralis (17\%) and Polyphaga aegyptiaca (8\%). Results of Arif et al. [27] revealed $P$. americana as the most prevailed (35.6\%) followed by B. orientalis (44\%) and B. germanica $(21.4 \%)$ in houses of Quetta. In the present study, American cockroach was observed the most abundant cockroach in the three unites of study viz wards (26.6\%), cafeteria (10.8\%), and lawns (5.8\%) compared to the other species (Table 1). Wards of BMC were more populated (20.8\%) than Benazir (18.3\%) and civil hospitals (16. 7\%). However, cafeteria of civil hospital was more populated (12.5\%) than same unites of other two hospitals $(10.8 \%)$ and $(7.5 \%)$ respectively. Lawns of all the three hospitals indicated least population of $P$. americana $(5.8 \%), B$. germanica $(2.5 \%)$, B. orientalis $(3.3 \%), B$. 
lateralis $(0.8 \%)$, and $P$. aegyptiaca $(0.8 \%)$ as shown in table 2 . In contrast to aforesaid four wards, the cardiac wards lack the presence of above mentioned five cockroach species because of sanitized it properly (Table 3). Hence, civil hospital has proven the most diverse composition with all three species found and the most prevailed for the American cockroach compared to the other study locations. However, more official buildings and hotel units require to be surveyed to confirm the findings.

Table 1. Percentage of Cockroach species trapped in different units of selected hospitals at Quetta city

\begin{tabular}{|l|c|c|c|c|}
\hline \multirow{2}{*}{ Study locations } & \multicolumn{3}{|c|}{ Units } & \multirow{2}{*}{ Total } \\
\cline { 2 - 4 } & Wards & Cafeteria & Lawn & $33.4 \%$ \\
\hline Civil hospital & $16.7 \%$ & $12.5 \%$ & $4.2 \%$ & $33.3 \%$ \\
\hline Bolan Medical Complex & $20.8 \%$ & $7.5 \%$ & $5.0 \%$ & $33.3 \%$ \\
\hline Benazir hospital & $18.3 \%$ & $10.8 \%$ & $4.2 \%$ & $100 \%$ \\
\hline Total & $55.8 \%$ & $30.8 \%$ & $13.4 \%$ & \\
\hline
\end{tabular}

Table 2. Trapped cockroach species from different localities of selected hospitals

\begin{tabular}{|l|c|c|c|c|}
\hline \multirow{2}{*}{ Cockroach species } & \multicolumn{3}{|c|}{ Sampling sites of hospitals } & \multirow{2}{*}{ Total } \\
\cline { 2 - 4 } & Wards & Cafeteria & Lawn & $43.3 \%$ \\
\hline P. Americana & $26.6 \%$ & $10.8 \%$ & $5.8 \%$ & $31.6 \%$ \\
\hline B. germanica & $15 \%$ & $14.1 \%$ & $2.5 \%$ & $20.8 \%$ \\
\hline B. lateralis & $14.1 \%$ & $3.3 \%$ & $3.3 \%$ & $3.3 \%$ \\
\hline P. aegyptiaca & - & $2.5 \%$ & $0.8 \%$ & $0.8 \%$ \\
\hline Total & - & - & $0.8 \%$ & $100 \%$ \\
\hline
\end{tabular}

Table 3. Total trap counts from various wards of selected hospitals

\begin{tabular}{|c|c|c|c|c|c|c|c|c|c|c|c|c|c|c|c|c|}
\hline \multirow{3}{*}{$\begin{array}{l}\text { Cockroach } \\
\text { species }\end{array}$} & \multicolumn{15}{|c|}{ Wards } & \multirow[b]{2}{*}{ Total } \\
\hline & \multicolumn{3}{|c|}{ Gynae } & \multicolumn{3}{|c|}{ Medicine } & \multicolumn{3}{|c|}{ Surgery } & \multicolumn{3}{|c|}{ Paeds } & \multicolumn{3}{|c|}{ Cardiac } & \\
\hline & $\mathbf{a}$ & b & c & $\mathbf{a}$ & b & c & a & b & c & a & b & c & $\mathbf{a}$ & b & c & \\
\hline P. americana & $5.8 \%$ & $4.2 \%$ & $2.5 \%$ & $3.3 \%$ & $2.5 \%$ & $0.8 \%$ & $1.7 \%$ & $0.8 \%$ & $1.7 \%$ & $0.8 \%$ & $1.7 \%$ & $0.8 \%$ & $0 \%$ & $0 \%$ & $0 \%$ & $26.6 \%$ \\
\hline B. ger & $1.7 \%$ & $1.7 \%$ & $0.8 \%$ & $2.5 \%$ & $1.7 \%$ & $0.8 \%$ & $0.8 \%$ & $1.7 \%$ & 0 & $0.8 \%$ & $2.5 \%$ & 0 & $0 \%$ & $0 \%$ & $0 \%$ & $15 \%$ \\
\hline B. orienta & $2.5 \%$ & $3.3 \%$ & $1.7 \%$ & $0.8 \%$ & $0.8 \%$ & $0.8 \%$ & $0.8 \%$ & $0 \%$ & $0.8 \%$ & $0 \%$ & $1.7 \%$ & $0.8 \%$ & $0 \%$ & $0 \%$ & $0 \%$ & $14.2 \%$ \\
\hline B. lateralis & - & - & - & - & & -1 & - & - & & - & & - & - & - & - & - \\
\hline P. aegyptiac & - & - & - & - & - & & - & & & & & - & - & - & - & - \\
\hline Total & $10 \%$ & $9.2 \%$ & $5 \%$ & $6.7 \%$ & $5 \%$ & $2.5 \%$ & $.3 \%$ & $2.5 \%$ & $2.5 \%$ & $1.7 \%$ & $5.8 \%$ & $1.7 \%$ & $0 \%$ & $0 \%$ & $0 \%$ & $55.8 \%$ \\
\hline
\end{tabular}

a. Civil hospital. b. Bolan medical complex. c. Benazir hospital

\section{Identified Cockroach species}

Based on main diagnostic features and using standard taxonomical key described by Chew et al. [24] four genera of cockroach species viz Periplenata americana, Blattella germanica, Blatta orientalis, Blatta lateralis and Polyphaga aegyptiaca belonging to three families, Blattidae, Blatellidae and Polyphagidae were identified.

Periplenata americana

Distribution and pest status

The $P$. americana cockroaches are considered as a major domiciliary pest distributed worldwide. 


\section{Identification and morphometrics Male}

The adult males $P$. americana were characterized by brownish red in color, pronotum almost smooth with yellow margins noted to be key identified feature in both male and female sexes. Wing spans exceeded little outside the abdomen (Figure 1c), legs bear spines, femur and tibia had thick spines on each pair of legs larger almost in third pairs, metatarsus was longer than other joints, cerci spinose, styles present between ceri. The measured body length was $4.3 \mathrm{~cm}$ with wing span.
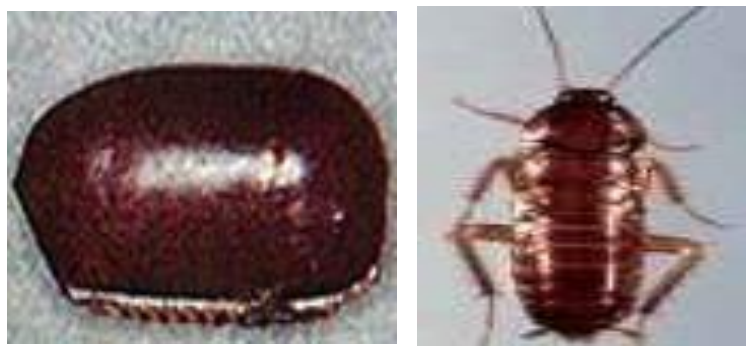

a. Egg (Ootheca)

b. Nymph (female)

Figure 1. Life stages of Periplenata americana

\section{Blatta orientalis \\ Distribution}

The oriental cockroach is second major outdoor pest. They can tolerate cool environment also but mostly harbor indoor spaces for their survival when there is temperature decline.

\section{Identified features and morphmetrics}

Male

The adult male $B$. orientalis were smaller in size than females about $2.8 \mathrm{~cm}$ in length (Figure 2c). Nymph passes through 6-8 molts become fully mature resemble with adults excluding wings (Figure 2b). Adults were black to dark brown in color, and possessing greasy shine (Figure $2 \mathrm{c} \& \mathrm{~d}$ ). Males had small tegmina (fore wings) and reduced hind wings which almost shielded

\section{Female}

The adult female $P$. americana were described by broadened and oval abdomen covered by overlapping fore-wings. Eggs (Ootheca) dark brown, 5 by $3 \mathrm{~mm}$ in length, head wider than that of males concealed by pronotum. Cerci present directed outwardly, style absent. Femur and tibia had thick spines whereas metatarsus was longer than other joints. The sub genital plate was posterior, symmetrical. Adult stage measured was $4 \mathrm{~cm}$ in length. Nymphs developed after 4 to 15 months which were quite similar with adults excluding wings (Figure 1b). Ootheca barrel-shaped almost dark-brown in color (Figure 1a).

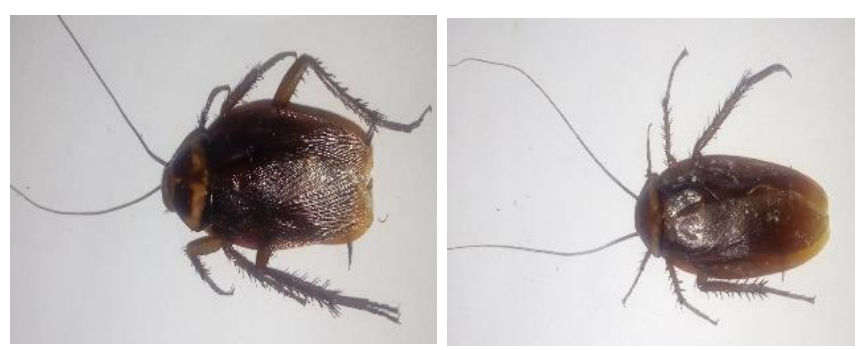

c. Adult male

d. Adult female

$3 / 4$ of the entire abdominal area. Cerci medium-sized directed outwardly, style absent. Femur slightly wider than tibia. Tibia had spines varied in thickness, almost 5 to 6 in number, tarsus longer than metatarsus

\section{Female}

Adult female was larger than male in body size measured $3.25 \mathrm{~cm}$ in length, black to dark brown in color exhibited greasy shine. (Figure 2d). Both sexes are no fliers. Females only have small wing pads on massive thoracic region. Adult cockroach also referred to as "water bug or black beetle". Femur possessed strong spines almost 7 in number. Sub genital plate noted to be similar to $B$. germanica. The nymph development was observed of oriental 
cockroach last for about 6-12 months, entirely wingless. Ootheca similar in shape and color to that of $P$. americana (Figure $2 a)$.
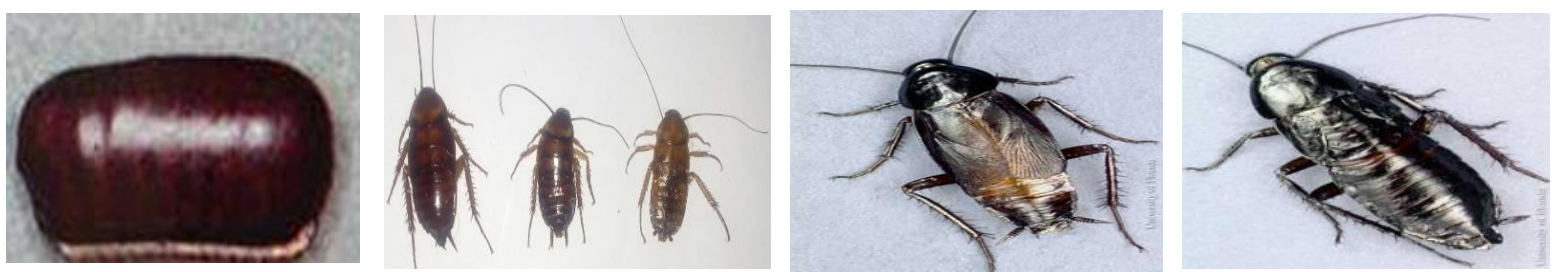

a. Egg (Ootheca) b. Nymphs (left|) fully mature c. Male (adult) d. Female (adult) Figure 2. Life stages of Blatta orientalis

\section{Blatella germanica}

\section{Distribution and pest status}

These are cosmopolitan insects among arthropods thought to be innate of Africa colonization, closely linked with human's lodging and human activities. They depend upon hot climate in homes and on another habitat. Some abiotic factors like water and food also affect their population.

\section{Identified features and morphometric Male}

The adult male $B$. germanica had thin body and pointed abdomen, color varied from yellow to black, the measured body length was about $1.5 \mathrm{~cm}$. Pronotum had two dark parallel lines running from head region to the base of the wings. Femur stout possessed strong spines, apparently 7 in numbers, ended with a large fur-like projection (Figure 3c). Flattened sub-genital plate was concealed by fore tegmina noted. The nymph development observed was last for about 6-12 months, entirely wingless (Figure 3b).

\section{Female}

The females were characterized by abdomen rounded posteriorly, body light brown in color with two dark longitudinal stripes on pronotum just behind the head (Figure 3d). Females possessed firm body entirely protected by outer wings. The Sub-genital plate rounded posteriorly equipped with ootheca visibly (Figure 3d). Femur stout having pointed spines appears to be 7 in numbers, the six ones' somewhat fur like in structure (Figure 3c). Cerci visible, mediumsized, directed outwardly. Adult was measured having $1.1 \mathrm{~cm}$ body length. The German cockroach reported to be swift runner and had rapid reproduction rate [19]. Nymph took $6-12$ weeks to fully mature (Figure 3b). Ootheca square shaped almost dark-brown in color (Figure 3a).
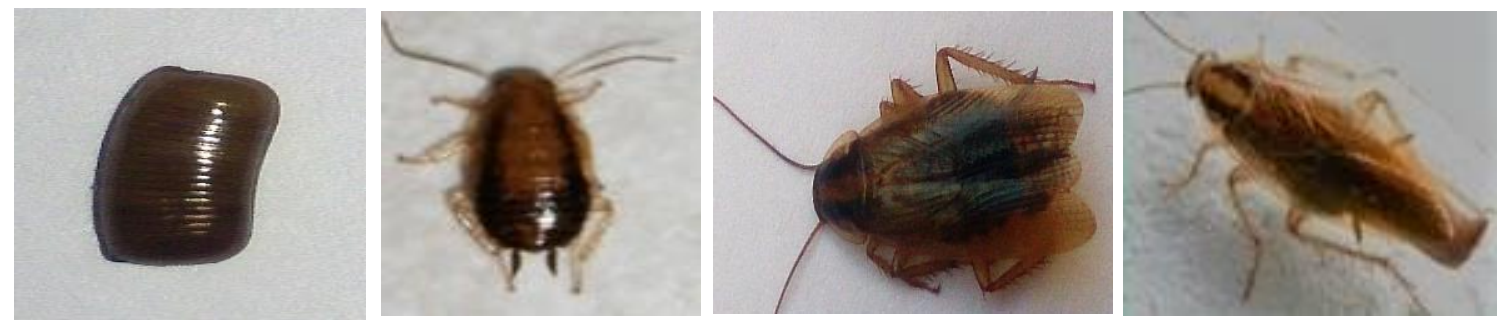

a. Egg (Ootheca) b. Nymph (mature) c. Male (adult) d. Female (adult) with ootheca Figure 3. Life stages of Blatella germanica 


\section{Polyphaga aegyptiaca \\ Distribution and pest status}

The Egyptian cockroach is one of the species that lives close to humans but it is uncommon house hold pest scared from other house hold pest thus, hardly appear at indoor areas. It can also live in harsh and semi-desert nature, and more commonly found in Asian and African countries. The males and females of this species are very dissimilar from each other, male looks like a black American cockroach, while the female resembles a wingless black beetle [28].

\section{Identified features and morphometrics Male}

The measured body length was $3.2 \mathrm{~cm}$, grayish black in color, smaller than female in length and width (Figure 4c). Antennae smaller in length relatively. In addition to variation in the size and color with the female; male had a distinct pronotum with straight edge posteriorly and laterally. Wings rounded at terminal end covered the thorax and abdomen. Tibiae spines (hind legs) arrow-shaped, four in number (Figure 4c), Cerci absent.

\section{Female}

Body somewhat oval in feature, $3.4 \mathrm{~cm}$ in length having broad thorax and abdomen, wingless, antennae small. Pronotum rounded laterally, females also had a separation line between inferior part of forehead and main part of face which is specific character of $P$. aegyptiaca. Tibiae spines (hind legs) arrowshaped, five in number (Figure 4d), cerci very short and un-segmented. Nymphs become mature after passes through 3 instars. Ootheca is pointed at one end and having 7-13 eggs (Figure 4a).
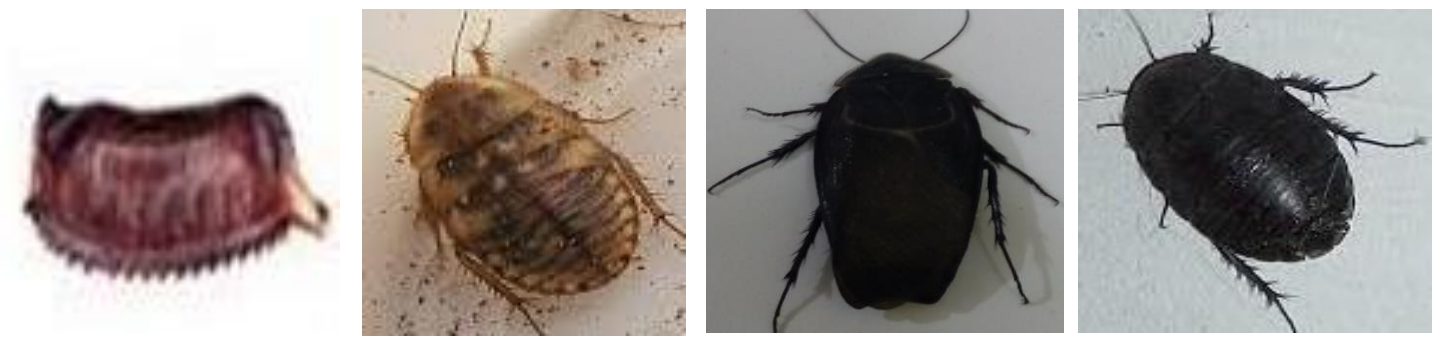
a. Egg (Ootheca)
b. Nymph
c. Male (adult)
d. Female (adult)
Figure 4. Life stages of Polyphaga aegyptiaca

\section{Blatta lateralis}

\section{Distribution and pest status}

Turkistan cockroach (B. lateralis) also known as the rusty red cockroach [29] is a primarily outdoor-dwelling cockroach native to an area from northern Africa to Central Asia [30]. Adult females are broader than males in diameter. This species is commonly occurring in field, house and specifically in steam tunnels. Researchers believe the species arrived on from central Asia, perhaps Afghanistan to urban areas of the southwestern US [31, 32].
Male

Adult male was medium sized, slender bodied cockroach measured around $1.9 \mathrm{~cm}$ in length, brownish orange in color with fully developed long, yellowish wings (Figure 4c). Wings were spreaded roof-like over body and exceeded little outside the abdomen. Tibia beard small spines on both sides, almost straight. Cerci present, antennae long. Nymphs were brown in front, black on the rear, and were wingless. 


\section{Female}

The adult female was dark brown to black, with cream-colored markings on the shield and a cream-colored stripe edging its tip (Figure 5d). This pest was measured about $2.0 \mathrm{~cm}$ in length, wings short, and vestigial.
Tibia beard large spine on the junction of tarsus, direct downward. Cerci present, slightly curved, antennae small compare to that of male cockroach. Ootheca slendershaped almost dark-red in color when examined (Figure 5a).

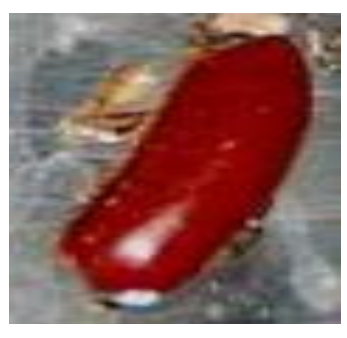

a. Egg (Ootheca)

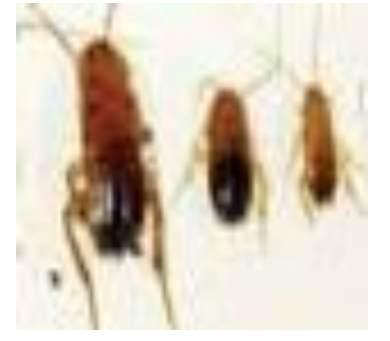

b. Nymphs

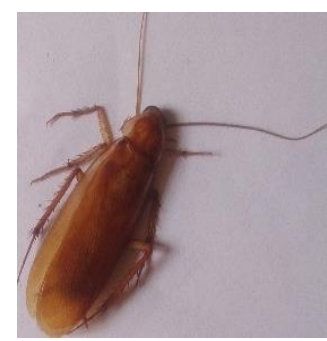

c. Male (adult)

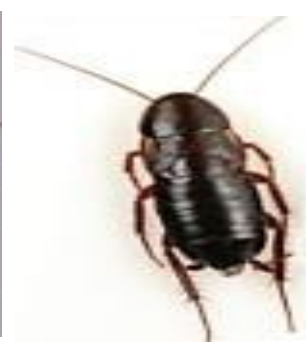

d. Female (adult) Figure 5. Life stages of Blatta lateralis (Turkistan cockroach)

\section{Discussion}

In this study 5 cockroaches species were identified from 360 specimens trapped in different locations of Quetta hospitals including: Periplaneta americana (Linnaeus, 1758), Blattella germanica (Linn.), Blatta orientalis (Linn.), Blatta lateralis (Linn.), and Polyphaga aegyptiaca (Linn.). The frequencies of collected cockroaches were get as: $(43.3 \%),(31.6 \%)$, $(20.8 \%),(3.3 \%)$, and $(0.8 \%)$ respectively. The American cockroach is known to be cosmopolitan pest. This study indicated that American cockroach was the most numerous and highly active nocturnal pest collected from hospitals followed by German cockroach. These findings are not in line with some studies [25-27], that $P$. americana have been showed as the most frequent species in the human lodging of Quetta followed by $B$. orientalis instead of $B$. germanica. However, our study is in line with the study of Ameri et al. [33] where they reported $P$. americana as the most frequent species captured from Tehran hospitals. Another resemblance between two studies is in the reporting of $B$. orientalis and $B$. germanica as one of the major cockroaches found in hospitals. Another key point in the current study is the reporting of Blatta lateralis (Linn.) and Polyphaga aegyptiaca (Liin.) from hospital environment. These two species have usually been reported in Quetta from kitchen areas of houses [26].

\section{Conclusions}

From the records of this study on dynamics of cockroach diversity in hospitals, it is concluded that the American, German, and Oriental cockroaches was the most common species found in Quetta hospitals. However, the main species was $P$. americana collected in the existing study. It is recommended that all the inspected hospitals, the reducing and eradication measures should be applied to decline the cockroach population as cockroach causes nuisances and allergic reactions. Therefore, it is suggested that breeding sites and food sources is necessarily be abolished and on threshold level low risk chemical control should be implicated to protect human health and environment. 


\section{Authors' contributions}

Conceived and designed the experiments: $S$ Gul \& A Kakar, Performed the experiments: S Gul, K Taj, F Abbas \& N Rafique, Analyzed the data:, S Gul \& A Kakar, Contributed reagents/ materials/ analysis tools:, S Gul \& S Gul, Wrote the paper: A Kakar \& S Gul.

\section{Acknowledgment}

Authors are grateful and would like to thank to hospitals' Medical Superintendent, other staff of hospitals and ward attendants for assistance in samples and data collection to complete this research work successfully.

\section{References}

1. Daly HV, Doyen JT \& Purcel Ill (1998). Daly and Doyen's Introduction to Insect Biology and Diversity. Whitfield, J. B. (Ed.). 3rd Ed, Oxford University Press P. 752.

2. Legendre F, Nel A., Svenson GJ, Robillard T, Pellens R \& Grandcolas P (2015). Phylogeny of Dictyoptera: dating the origin of cockroaches, praying mantises and termites with molecular data and controlled fossil evidence. PLoS ONE 10(7): e0130127.

3. Salehzadeh A (1992). An investigation on insects and determination of their sensitivity to Faykam and Lindan's pesticides in Hamadan. J Scient Res Affair 2:32-36.

4. Nejati J, Keyhani A, Moosa-Kazemi SH, Mohammadi M, Mahjoob M \& Boostanbakhsh A (2012). Cockroaches' bacterial infections in wards of hospitals, Hamedan city, west of Iran. Asian Pac J Trop Dis 2: 381-4.

5. Muhammadi J (1998). Determination of active specimens of cockroach in hospitals and dwellings of Zanjan, Province. First Medical Entomology Congress, Pastor Institute, Tehran, Iran. p.139.

6. Cochran DJ (2001). Cockroaches: Biology distribution and control. $1^{\text {st }}$ ed, Tehran University Publication p.144.
7. Kopanic RJ, Sheldon B \& Wright C (1994). Cockroaches as vector of Salmonella: Laboratory and Field Trials. J Food Protect 57: 125-132.

8. Stankus RP, Horner WE \& Lehrer SB (1990). Identification and characterization of important cockroach's allergens. J Allergy Clin Immunol 86 (5): 781-787.

9. $\mathrm{Lu} \mathrm{W}$, Valentine BD, Perez-Gelabert DE \& Esteban Gutiérrez E (2014). Ecology and Diversity of Cockroaches (Dictyoptera: Blattaria) from the Virgin Islands. Insecta Mundi 0349: 1-32.

10. Lynch S (2007). Who's the cockroach. Entomololgy 7(3): 15-17.

11. Rivault C, Cloarec A \& Guyader LA (1993). Bacterial load of cockroaches in relation to urban environment. Epidemiol Infect 110(2): 317-325.

12. Bonnefoy $X$, Kampen H \& Sweeney K (2008). Public Health Significance of Urban Pests. Publishing Company DK2100 Copenhagen Denmark p.565.

13. Cochran D G (1999). Cockroaches: their biology, distribution and control. Geneva, WHO. Document No:WHO/CDS/CPC/WHOPES/99.3.ac cessed:2006 July 20th.

14. Dubus J, Guerra M \& Bodiou A (2001). Cockroach allergy and asthma. Biology and diversity. $2^{\text {nd }}$ ed, Oxford Univ. Press, London. 56 (4): 351-352.

15. Menasria T, Moussa F, Souad ElHamza S, Tine S, Megri R \& Chenchouni H (2017). Bacterial load of German cockroach (Blattella germanica) found in hospital environment. Pathog Glob Health 108(3): 141-147.

16. Cloarec A, Rivault C, Fontaine F \& Le Guyader A (1992). Cockroaches as carriers of bacteria in multi-family dwellings. Epidemiol Infect 9(3): 48390. 
17. David BV \& Ananthakrishnan $\mathrm{TN}$ (2004). General and Applied Entomology, Taxonomy. $\quad 2^{\text {nd }}$ ed, McGraw-Hill Publications p. 317-321.

18. Robinson WH (1996). Urban Entomology: Insect and mite pests in the human environment. Springer.

19. Gore JC \& Schal C (2005). Expression, Production and Excretion of Bla g1, a major human allergen, in relation to intake in the German cockroach, Blatella germanica. Med Vet Entomol 19: 127-134.

20. Edwards JP \& Short JE (1993). Elimination of population of the oriental cockroach (Dictyoptera: Blattidae) in a simulated domestic environment with the insect hormone analogue (S)Hydroprene. J Econ Entomol 78(86): 436-443.

21. Jordan EL \& Verma PS (2006). Invertebrate Zoology. S. Chand \& Company Ltd. New Delhi, India p. 1018.

22. Koehler PG, Bayer BE \&d Branscome D (2013). Cockroaches and their management, University of Florida (UF), Institute of Food and Agriculture sciences (IFAS) Extension p.1-6.

23. Oliva GR, Díaz C, Fuentes G O, Martínez MD, Fernández $\mathrm{C} \&$ Cordovi $R$ (2010). Blattella germanica as a possible cockroach vector of microorganisms in a hospital. $J$ Hosp Infect 74: 93-95.

24. Chew G L, Carlton EJ, Kass D, Hernandez M, Clarke B, Tiven J, Garfinkel R \& Evans ASD (2006). Determinants of cockroach and mouse exposure and associations with asthma in families and elderly individuals in New York City public housing.Ann Aller Asth Immunol 9(7): 502-5013.
25. Masood A, Robert S, Ahmed HA, Sajjad N \& Tariq N (2014). Detection of cockroaches as mechanical carrier of Escherichia coli and Salmonella species. Afr $J$ Microbiol Res 8(42):3625-3629.

26. Taj MK, Essote SA, Arif S, Kamran K, Tariq JA, Shaheen U, Taj I, Ahmed Z, Haq AU, Muhammad G \& Ahmed A (2017). Biodiversity of Cockroaches from houses of Quetta city, Balochistan. Int J Biosci 10(1): 368-373.

27. Arif S, Taj MK, Kamran K, Iqbal A, Taj M, Mohammad G, Hussain K \& Ahmed A (2017). House hold cockroaches of Quetta city as reservoir for infectious pathogenic bacteria. J Entomol Zool Stud 5(1): 649-653.

28. Beccaloni G \& Eggleton P (2013). Order Blattodea. Zootaxa 3703(1): 046- 048.

29. Anonymous (2014). Taxonomic information for Turkistan cockroach, Blatta (Shelfordella) lateralis. Encyclopedia of Life.

30. Kim T \& Michael KR (2013). Life History and Biology of the Invasive Turkistan Cockroach (Dictyoptera: Blattidae). J Econ Entomol 106 (6): 2428-2432.

31. Werner FG \& Olson CE (1994). Insects of the Southwest. Fisher Books. p. 5-6. ISBN 978-1-55561-060-9. Retrieved December 13, 2013.

32. Geoffrey M (2013). "Military, not the Internet, blamed for invasive cockroach". Los Angeles Times. Retrieved 13 December 2013.

33. Ameri A, Vazirianzadeh B, Ehdaei B, Motamedi H, Sadeghabadi ZA, Ghanbari M \& Asmar A (2013). Identification of collected cockroaches from Ahvaz hospitals, south-west of Iran. J Exp Zool India 16(2): 709-710. 